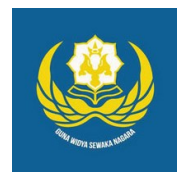

Jurnal Analogi Hukum

Journal Homepage: https://ejournal.warmadewa.ac.id/index.php/analogihukum

\title{
Pembayaran Uang Pengganti Oleh Terpidana Dalam Kasus Tindak Pidana Korupsi Studi Kasus Putusan Mahkamah Agung Nomor 520 K/Pid.Sus/2017 (Payment Of Substitute Money By Convicted Persons In Cases Of Corruption Case Study Of Supreme Court Decision Number 520 K/Pid.Sus/2017)
}

\author{
Anak Agung Ananda Putra Pangjaya *, A.A Sagung Laksmi Dewi dan I Nyoman Sujana \\ Universitas Warmadewa, Denpasar-Bali, Indonesia \\ *pangjaya@gmail.com \\ Pangjaya, A, A, A, P., Dewi, A, A, S, L., Sujana, I, N.(2019). Pembayaran Uang Pengganti Oleh Terpidana Dalam Kasus Tindak Pidana Korupsi \\ Studi Kasus Putusan Mahkamah Agung Nomor 520 K/Pid.Sus/2017 (Payment Of Substitute Money By Convicted Persons In Cases \\ Of Corruption Case Study Of Supreme Court Decision Number 520 K/Pid.Sus/2017). Jurnal Analogi Hukum. 2 (1). 1-6. Doi: http:// \\ dx.doi.org/10.22225/.2.1.1603.1-6
}

How To Cite:

\begin{abstract}
Evasion of money or fraud in using power is a complex problem that must be addressed, in order to achieve just and healthy and advanced economic growth and conditions. In the face of the complexity of the problem of corruption so far, it is wrong to fight the crime of embezzlement of money that has been known to be through means of criminal law as a criminal policy tool in combating or eradicating crime. compensation payments in cases of corruption include additional penalties other than decisions on criminal penalties and fines, there are also a number of problems here, namely, how to regulate substitute money payments made by convicted corruption cases and how the judge considers the payment of substitute money as a basis carried out by convicted cases of corruption. This type of research is normative juridical with the approach used, namely the negotiation approach and presented descriptively. The results of the discussion show that the voluntary implementation by the convict for a period of 1 (one) month after the Supreme Court Decision Number $520 \mathrm{~K} /$ PID.SUS / 2017 dated June 20, 2017 is a cumulative imperative and it fulfills the judicial and non-judicial aspects of judges' judgments. The advice that can be given is the payment of substitute money must be really carried out in the verdict and not until the imposition of criminal corruption only pays a fine with the transfer of the case only as a mistake administration of judges' decisions must fulfill juridical and non-juridical aspects but not ultra-light that the judge does not may impose a sentence higher than the maximum threat in the indicted market.
\end{abstract}

Keywords: Convicted, Corruption, Replacement Money

\begin{abstract}
Abstrak-Penggelapan uang atau penyelewengan dalam menggunakan kekuasaan merupakan permasalahan yang komplek yang harus ditangani, agar tercapai pertumbuhan dan kondisi ekonomi yang adil dan sehat serta maju. Dalam menghadapi kompleksitas selama ini masalah korupsi, maka salah satu memerangi kejahatan penggelapan uang yang selama ini diketahui adalah melalui sarana hukum pidana sebagai alat kebijakan kriminal dalam memerangi atau memberantas kejahatan. Pembayaran ganti kerugian dalam kasus tindak pidana korupsi termasuk dalam pidana tambahan selain dari putusan penjatuhan hukuman pidana dan denda, adapun permasalahan yang diangkat disini yaitu, bagaimana pengaturan Pembayaran uang pengganti yang dilakukan oleh terpidana kasus tindak korupsi Dan bagaimana dasar pertimbangan hakim dalam Pembayaran uang pengganti yang dilakukan oleh terpidana kasus tindak pidana korupsi. Tipe penelitian ini adalah yuridis normatif denga pendekatan yang digunakan yaitu pendekatan perundang-undangan dan disajikan secara deskriptif. Hasil pembahasan menunjukan bahwa pelaksanaa secara sukarela oleh terpidana selama tenggang waktu 1 (satu) bulan sesudah Putusan Mahkamah Agung Nomor 520 K/PID.SUS/2017 tertanggal 20 Juni 2017 bersifat imperatif komulatif dan sudah memenuhi aspek pertimbangan yuridis dan non yuridis hakim. Adapun saran yang dapat diberikan adalah pembayaran uang pengganti harus benar-benar dilaksanakan dalam penjatuhan vonisnya dan jangan sampai penjatuhan pidana korupsi hanya membayar denda saja dengan pengalihan kasusnya hanya sebagai kesalah administrasi putusan hakim harus memenuhi aspek yuridis dan
\end{abstract}


non yuridis namun tidak ultra pelita yaitu hakim tidak boleh menjatuhkan hukuman lebih tinggi daripada ancaman maksimum dalam pasal yang didakwakan.

Kata Kunci: Terpidana, Korupsi, Uang Pengganti

\section{Pendahuluan}

Cita-cita negeri kita Indonesia untuk mewujudkan rasa keadilan, aman, tentram, damai dan sejahtera yang berlandaskan pancasila sebagai ideologi bangsa ini. Lebih menekankan kembali pada program hal memerangi kejahatan yang pada umumnya bersifat pidana dan dalam kejahatan penyelewengan uang. Ini dilaksaksanakan agar menjaga ketertiban dan keadilan bagi setiap individu yang ada.

Pada masa pembangunan saat ini berbagai permasalahan penggelapan uang dengan angka nominal mulai dari kecil ataupun hingga beriburibu bahkan berjuta-juta dolar sangat sering dijumpai. Banyaknya kalangan elite politik sering menjadi berita di media masa karena terkena operasi tangkap tangan yang dilakukan pihak-pihak berwajib. Seperti tidak merasa jera dengan apa yang menimpa pejabat-pejabat tersebut, sehingga itu seperti semacam virus yang menular. Orang-orang yang bersangkutan tersebut lupa dengan sumpah yang ia ucapkan saat ia diberikan penugasan atau dilantik. Tidak peduli dengan apa yang terjadi dipikiran mereka ialah agar tercapainya tujuan mereka dalam memperkaya diri sendiri.

Orang yang berkuasa apabila sudah mendapatkan kedudukan dan waktu serta dana yang melimpah pasti akan menimbulkan niat jahat untuk melakukan penggelapan tersebut. Masalah penggelapan ini sepertinya sudah menjadi wabah penyakit yang merajalela pada saat era reformasi ini. Setiap tahunnya permasalahan pengelapan uang negara, konspirasi serta diskriminasi selalu meningkat pesat.

Berbagai faktor yang menjadikan sorang menjadikan dirinya tersangka dalam kegiatan kasus penyelewengan. Kesenjangan dalam hidup sosial serta ekonomi dengan dibarengi kebutuhan hidup yang banyak, adanya mental serta moral yang sudah terkena sugesti penggelapan bahkan akibat dari lingkungan sosialnya berada. Hanya demi keuntungan pribadi semata dengan pemanfaatan kewenangan yang ada dimiliki sekarang merupakan modal utama dalam melakukan kejahatan penggelapan serta penyelewengan ini (Hamzah, 2008).

Tidak hanya terdapat di Indonesia bahkan di negara-negara maju pun tak luput dari permasalahan penggelapan untuk memperkaya diri sendiri ini, permasalahan seperti ini pun banyak mendapatkan sorotan dan penangan yang serius di negara negara selain Indonesia dan tidak bisa dipungkiri hukumannya bisa lebih kejam dibandingan Indonesia.

Penggelapan uang adalah sebuah kegiatan dimana untuk memperkaya dirinya dengan melaksanakan tindakan cukup meresahkan negara. Ini merupakan kejahatan yang dikategorikan sebagai kejahatan yang luar biasa. Tidak memperdulikan norma yang ada dan berlaku yang ada dan hanya melewati aturan batasan serta menggunakan kewenangan sesuka hatinya. (Ibid:33)

Adanya waktu serta ruang yang terlihat jelas didepan mata. Tak bisa menghindarkan seseorang dari proses penggelapan ini. Penyelewengan uang negara ini merupakan masalah yang sangat kompleks diharuskan mendapatkan tindakan setegas mungkin demi kelangsungan kehidupan yang lebih adil dan sejahtera bagi Indonesia. Hal ini bertujuan agar pembangunan saat ini lebih maju kedepan dengan cara memerangi tindakan yang tidak terpuji seperti penggelapan, konspirasi serta diskriminasi yang ada saat ini.

Adanya Undang-Undang No 31 tahun 1999 tentang pemberantasan tindak pidana penggelapan diharapkan mampu dalam memerangi masalah kejatan penggelapan penyelewengan, bahkan konspirasi di negeri ini. Sebagai sarana dalam meberikan hak-hak perlindungan kepastian hukum dalam masyarakat ekonomi saat ini. Memerangi kejahatan penggelapan dengan sikap jujur serta adil yang tidak pandang bulu. Serta tidak menghabiskan banyak waktu, biaya bahkan tenaga. Biasanya hanya kalangan elit saja yang tertangkap kasus seperti ini. Ada satu kasus di daerah saya yaitu seorang dengan inisial IGW bertindak dengan kekuasaan yang diraih saat itu menjadi seorang bupati, melakukan kejahatan luar biasa dalam penggelapan dana. Yang menharuskan ia diberi ganjaran hukum 3.5 tahun penjaran disertai denda 50 juta. Dalam putusan MA lebih berat dibandingan putusan tipikor Denpasar dalam putusan MA ia diwajibkan membayar ganti rugi sebanyak 2.322 milyar.

Penelitian sebelumnya yang berkaitan dengan tindak pidana korupsi juga dilakukan oleh (Rohrohmana, 2017) yang berfokus pada 
pidana pembayaran uang pengganti sebagai pidana tambahan dalam tindak pidana korupsi menunjukkan bahwa rasionalisasi pandangan JPU diantaranya berorientasi pada tujuan dari pemberantasan korupsi sebagai upaya konkrit mengembalikan kerugian negara, dan tidak sekedar menjerakan pelaku TPK. Sementara itu, penelitian serupa juga dilakukan oleh (Hikmawati, 2019) yang berfokus mengkaji pengembalian kerugian keuangan negara dari pembayaran uang pengganti dalam tindak pidana korupsi dapatkah optimal? Menunjukkan bahwa pidana pembayaran uang pengganti telah diatur dalam UU No. 31 Tahun 1999 tentang Pemberantasan Tindak Pidana Korupsi sebagaimana telah diubah dengan UU No. 20 Tahun 2001. Jumlah pembayaran uang pengganti sebanyak- banyaknya sama dengan harta benda yang diperoleh dari tindak pidana korupsi. Apabila uang pengganti tidak dibayar, maka terpidana dipidana dengan pidana penjara yang lamanya tidak melebihi ancaman maksimum dari pidana pokoknya. Oleh karena itu, pengembalian kerugian keuangan negara tidak dapat optimal. Jumlah pengganti kerugian keuangan negara perlu ditingkatkan, dengan melakukan penyitaan dan perampasan terhadap aset/harta kekayaan pelaku. UU Perampasan Aset perlu dibentuk sebagai dasar hukum perampasan aset dari hasil korupsi.

Berdasarkan dari uraian latar belakang diatas adapun rumusan masalah yang akan penulis bahas, yaitu:

Bagaimana pengaturan pembayaran uang pengganti yang dilakukan oleh terpidana kasus tindak pidana korupsi?

Bagaimana pertimbangan hakim dalam pembayaran uang pengganti yang dilakukan oleh terpidana kasus tindak pidana korupsi?

Setiap penelitian memiliki tujuan, adapun tujuan dari penelitian ini, yaitu:

Untuk mengetahui bagaimana pengaturan pembayaran uang pengganti yang dilakukan oleh terpidana kasus tindak pidana korupsi.

Untuk mengetahui pertimbangan hakim dalam pembayaran uang pengganti yang dilakukan oleh terpidana kasus tindak pidana korupsi

Dalam penelitian ini penulis menggunakan metode penelitian hukum normatif yaitu yang dimana dengan cara melakukan pengkajian terhadap bahan hukum dari literatur. Dalam penelitian ini penulis menggunakan pendekatan masalah yaitu pendekatan secara perundangundangan dan pendekatan secara konseptual.
Pendekatan perundang-undangan ialah suatu pendekatan dimana suatu peraturan perundangundangan dikaji lebih dalam dan khusus peraturan perundang-undangan tersebut juga berhubungan dengan permasalahan yang ada. Sedangkan pendekatan konseptual merupakan suatu pendekatan yang di dalam ilmu hukum ada dan bekembang pemikiran dan doktrin para sarjana.

Adapun sumber bahan hukum yang digunakan penulis akan digunakan yaitu bersumber dari penelitian dan kepustakaan, berupa:

Bahan hukum primer adalah bahan hukum yang sifatnya mengikat berupa peraturan perundang-undangan yang berlaku dan ada kaitannya dengan permasalahan yang dibahas meiputi: Undang-undang No. 8 tahun 1981 tentang kitab undang-undang hukum acara pidana; Undang-Undang No 31 tahun 1999 tentang pemberantasan tindak pidana korupsi.

Bahan hukum sekunder adalah bahan hukum yang sifatnya menjelaskan bahan hukum primer, dimana bahan hukum sekunder berupa buku literatur, hasil karya sarjana untuk memperluas wawasan penulis mengenai bidang penulisan.

Bahan hukum tersier yaitu bahan yang memberikan petunjuk maupun penjelasan terhadap bahan hukum primer dan sekunder, contohnya kamus.

Teknik yang digunakan untuk pengumpulan bahan hukum yang diperlukan dalam penelitian ini diperoleh dengan cara melakukan studi kepustakaan. dengan cara mencari, meringkas, mencatat dan mempelajari serta memahami buku-buku ilmiah yang memuat pendapat beberapa sarjana. Bahan hukum yang telah berhasil dikumpulkan tersebut selanjutnya akan dilakukan penyuntingan bahan hukum, pengklarifikasian bahan hukum yang relevan dan penguraian secara sistematis.

\section{Hasil Penelitian dan Pembahasan}

\section{Pengaturan Pembayaran Uang Pengganti Oleh Terpidana Dalam Kasus Tindak Pidana Korupsi}

Korupsi sebuah kata dimana saat ini hangat -hangatnya diperbincangkan di masyarakat, banyaknya kalangan elite politik yang terjerat dalam kasus penggelapan uang negara ini menyebabkan hilangnya rasa kepercayaan masyarakat terhadap orang-orang yang 
diamanatkan sebagai pembela aspirasi rakat ini malah bertindak tidak terpuji dengan menyelewengkan hak-hak rakyat untuk kepentingan diri sendiri. Termasuk kedalam tindak pidana khusus penggelapan atau korupsi ini sudah ditetapkan dalam perundangundangan dalam ketentuan hukum positif.

Korupsi mendapat berbagai pengertian di Indonesia mulai dari korupsi merupakan suatu kejahatan perbuatan yang menimbulkan kerugian materiil negara, perbuatan yang tidak terpuji, suatu srategi dalam berbuat curang demi pemuasan keinginan semata. Tidak adanya itikad baik, moral serta ketidakjujuran dalam diri sendiri melakukan kebohongan publik.

Mengenai penjatuhan hukuman terhadap terdakwa pidana penggelapan uang negara kedalam termasuk yaitu bersifat imperatif serta fakultaif. Pemberian hukuman kepada terdakwa dapat berupa hukuman penjara maupun pembayaran denda atau fakultatif (Dipradja, 1990).

Selain dari kedua yang disebutkan diatas jenis hukuman seperti perampasan atau penyitaan aset-aset berharga milik yang bersangkutan dapat dilakukan terhadap barang yang berwujud maupun tidak berwujud dalam konteks alasan-alasan mengenai barang yang tidak bisa dirampas apabila barang tersebut sudah tidak ada atau telah dihilangkan oleh yang bersangkutan.

Dalam undang-undang ini kegiatan penyitaan yang dilaksanakan oleh pihak yang berwajib ini merupakan suatu bentuk ganti rugi atau pengganti kerugian yang diakibatkan oleh yang bersangkutan karena negara mengalami kerugian atas kelakukan yang dibuatnya. Tidaklah salah apabila semua benda atau barang yang mempunyai hak atas diri yang bersangkutan ikut diperiksa dalam permasalahan ini bahkan keluarga tidak luput dari pemeriksaan atas kerugian ini. Aset kekayaan yang dicurigai sebagai hasil dari penggelapan selama ini akan disita dan dipublikasikan secara umum baik media masa maupun media cetak seperti yang tejadi belakangan ini yang banyak menimpa kalangan elit pejabat.

Pembayaran ganti rugi tidak sama dengan jenis pembayaran denda. Denda memang sudah ditetapkan dalam aturan sedangkan ganti rugi berupa uang tersebut merupakan ganti rugi akibat kerugian yang dialami negara sebab kelakuan dari yang bersangkutan. Semakin banyak negara mengalami kerugian maka ganti rugi pun akan semakin banyak pula ini sangat berjalan dengan lurus. Dengan dilaksanakannya penggantian uang yang telah digelapkan ini diharapkan mampu memulihkan kondisi ekonomi yang sudah rusak menjadi sehat kembali dengan pemulihan kas keuangan agar berjalan stabil, tidak semata-mata ini sebagai hukuman saja melainkan agar orang yang melakukan perbuatan semacam ini merasakan efek dari perbuatan yang dilaksanakan dengan memanfaatkan kewenangan yang ia miliki.

Pelaksanaan pembayaran uang pengganti dilaksanakan dengan ikhlas dengan pemberian waktu sebulan setelah tetapan pengadilan memiliki kekuatan hukum tetap. Apabila yang bersangkutan tidak mebayar sesuai dengan vonis yang sudah ditetapkan maka jaksa berhak melaksanakan penyitaan terhadap aset milik terpidana dan kemudian akan dilaksanakannya proses pelelangan guna menutupi semua kerugian yang di timbulkan dari masalah yang terjadi.(Ibid:99)

Apabila harta bendanya tidak mencukupi untuk menutupi kerugian yang ditimbulkan pada negara maka penyitaan terhadap barang milik pihak ketiga pun dapat dilakukan karena adanya itikad tidak baik dalam pihak ketiga ini, walaupun dalam Undang-Undang sudah diatur tidak diperbolehkan untuk melakukan perampasan terhadap barang hak milik orang lain. Namun dalam hal ini apabila ditemukannya hasil penggelapan yang dimasukkan ke dalam tabungan ataupun rekening baik yang sudah berbentuk barang atau masih dalam keadaan uang pihak ketiga ini dimunginkan melakukan penyitaan aset terhadap pihak ketiga tersebut. Seandainya dalam pihak ketiga ini merasa tidak pernah mendapatkan uang atau barang dari hasil penggelapan ini maka pihak ketiga boleh mengajukan surat keberatan kepada pengadilan.

\section{Dasar Pertimbangan Hakim Dalam Pembayaran Uang Pengganti Yang Dilakukan Oleh Terpidana Kasus Tindak Pidana Korupsi}

Bukan hal yang baru lagi korupsi atau penggelapan yang merugikan bangsa saat ini peredarannya sama dengan permasalah narkoba di negeri ini. Seperti sebuah virus yang perkembangannya sangat cepat baik di kalangan teratas bahkan samapi ke pelosokpelosok daerah. Vonis hukumannya pun berbagai macam dan berbeda-beda tergantung berat sedangnya kerugian yang dialami karena perbuatan tersebut. Contohnya seperti masalah yang melibatkan mantan bupati jembrana atas nama IGW yang disidangakan pada juni 2017 lalu bertempat di pengadilan Tipikor denpasar 

Study Of Supreme Court Decision Number 520 K/Pid.Sus/2017)

\section{(Setiadi \& Rena, 2010).}

Beliau didakwa dalam kasus penggelapan uang negara untuk memperkaya dirinya sendiri dalam hal ini ia tidak sendirian melainkan bersama dua orang rekannya yang diproses secara berbeda. Kejadian tersebut dilakukannya sekitar tahun 2009 sampai dengan tahun 2010 yang bertempat di kantor bupati jembrana diketahui melakukan suatu perbuatan melawan hukum melewati batas-batas aturan yang sudah ditetapkan, merugikan negara.

Dia dengan jelas dan sah telah melakukan penyelewengan dana beasiswa stikes kemudian IGW divonis bersalah dan mendapatkan hukuman 3.5 tahun penjara serta $\mathrm{Rp}$. 50 juta denda yang harus dibayarkan. Hal ini tidak sepadan dengan apa yang telah ditimbulkan oleh terpidana ini termasuk dalam hukuman sedang, karena dalam proses pemberian beasiswa kepada mahasiswa STKS tidak sesuai dengan peraturan bupati jembrana yang telah ditetapkan.

Kerugian ini menimbulkan kerugian lebih dari 2 milyar. Uang sebanyak ini masuk ke kantong pribadi terdakwa yang saat itu menjabat sebagai bupati jembrana. Dengan uang sebanyak itu bertujuan memperkaya dirinya sendiri dan kabupaten jembrana mengalami kerugian yang nominalnya sangat besar akibat kelakuan mantan bupati tersebut.

Namun vonis yang ditetapkan pengadilan tinggi ini membuat rasa kecewa dirasakan hukuman yang dijatuhkan tersebut masih dalam kategori ringan mengingat terpidana IGW telah terbukti dan sah melakukan kejahatan penggelapan dan kejahatan berlanjut. Dalam vonis yang ditetapkan oleh MA lebih berat dibandingakan vonis pengadilan tipikor. Dalam hal ini MA menetapkan terdakwa dengan penjara paling lama tujuh tahun serta denda paling banyak lima ratus juta rupiah. Yang bersangkutan pun harus menbayar ganti rugi yang disebabkan olehnya. Sebanyak 2 milyar lebih.

Dengan syarat apabila tergugat tidak membayar uang yang telah ditentukan sebagaimana hasil dari vonis yang telah diberikan masa tenggang selama satu bulan setelah vonis yang sudah mempunyai hukum mutlak, bahwa segala aset berharga yang berwujud maupun tidak berwujud dapat disita dan dilaksanakannya pelelangan guna memperbaiki keuangan yang dirusaknya. Apabila tidak ada aset yang dapat diuangkan hukuman penjara ditambah 3 tahun kurungan penjara.
Dalam hal ini dasar pertimbangan hakim memberikan hukuman kepada yang bersangkutan IGW hakim melihat dari macam sudut hukum dan alat-alat bukti yang jelas ada yang memenuhi unsur menguntungankan diri sendiri dengan mengeruk uang negara, tidak mempunyai itikad baik dalam melaksanakan tugasnya sebagai bupati dan menyelewengan dana beasiswa bagi mahasiswa STIKES, salah mepergunakan kekuasaannya untuk kepentingan pribadi.

Hukuman ini sangat tidak seimbang dengan penjatuhan hukuman yang pertama. Disini kita tidak bisa menyalahkan hakim dan mempertanyakan hakim dengan vonisnya tersebut, banyak faktor yang mempengaruhi mungkin saja dalam hal ini dalam tingkat penyidikannya alat bukti yang ditemukan minim sehingga sedikitlah tuntutan yang diterima oleh hakim.

\section{Simpulan}

Tindak pidana korupsi suatu tindak pidana khusus. Bentuk pidana pokok selama hukum pidana korupsi mirip atas jenis pidana pokok dalam KUHP, berlainan perihal atas tipe pidana tambahan UU PTPK yang mengatur pemberian uang pengganti yang nominalnya sebanyakbanyaknya mirip atas harta benda yang didapatkan atas hasil tindak pidana korupsi. Proses pemberian uang ganti rugi dilaksanakan atas cara menagih Pembayaran atau pelaksanaan secara ikhlas oleh yang bersangkutan bertenggang waktu 1 (satu) bulan setelah vonis pengadilan memilik kekuatan hukum pasti. Jika selama waktu tenggang yang diberikan tidak juga ada itikad untuk membayar, bisa dilaksanakan penyitaan harta benda yang bersangkutan untuk diadkan lelang.

Dasar pertimbangan hakim yakni pertimbangan yuridis yaitu berdasarkan alat-alat bukti yang jelas perbuatan terdakwa memenuhi unsur-unsur menguntungkan diri sendiri atau orang lain. Menyalahgunakan kewenangan yang dimiliki serta dasar pertimbangan non yuridis yaitu mempertimbangkan berat ringannya pidana penggelapan hakim harus mempertimbangkan hal-hal yang memberatkan dan meringankan terdakwa.

Penelitian ini dapat menjadi pertimbangan bagi pemerintah dan pihak yang berwenang mengatasi masalah korupsi ini dimohonkan agar lebih menambah landasan hukum untuk mengatasi masalah penggelapan, konspirasi dan diskriminasi yang dilakukan elit-elit politik. Bagi 
masyarakat diharapkan agara selalu bekerja dengan itikad baik dan tulus. Jangan samapi tergoda untuk melakukan kegiatan yang tercela seperti korupsi. Untuk pejabat ataupun semua orang dimohonkan agar bekerja dengan hati nurani apabila sudah terjadi kejadian seperti ini dihartapkan mampu menjadikannya sebagai pelajaran yang berharga.

\section{Daftar Pustaka}

Dipradja, A. S. (1990). Hukum Pidana dalam Yurisprudensi. Bandung: Armico.

Hamzah, A. (2008). Pemberantasan Korupsi Melalu Hukum Pidana Nasional dan Internasional. Jakarta: Raja Grafindo.

Hikmawati, P. (2019). Pengembalian Kerugian Keuangan Negara dari Pembayaran Uang Pengganti Tindak Pidana Korupsi, Dapatkah Optimal? (Return of State Financial Losses from The Payment of Substitute Money Corruption Criminal Act, Can It Be Optimal?). Negara Hukum: Membangun Hukum Untuk Keadilan Dan Kesejahteraan, 10(1), 89-107. doi:10.22212/jnh.v10i1.1217

Rohrohmana, B. (2017). Pidana pembayaran uang pengganti sebagai pidana tambahan dalam tindak pidana korupsi, 6(1), 44-65.

Setiadi, E., \& Rena, Y. (2010). Hukum Pidana Ekonomi. Jakarta: Sinar Garfika.

Undang-undang No. 8 tahun 1981 tentang kitab undang-undang hukum acara pidana.

Undang-Undang No 31 tahun 1999 tentang pemberantasan tindak pidana korupsi. 